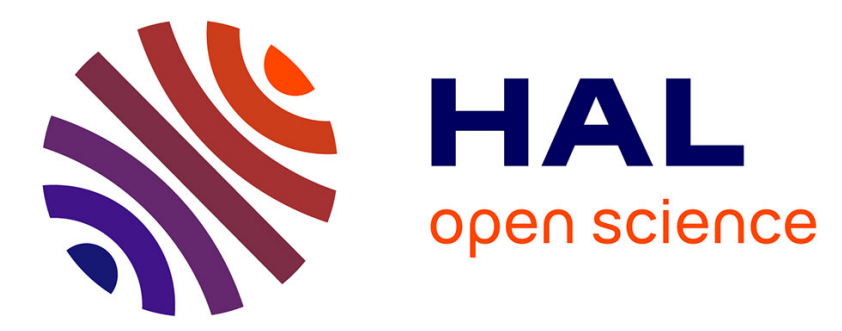

\title{
Software-assisted Computed Tomography Quantification of Airway Remodeling in the Normal Aging Process
}

Sébastien Bommart, Hélène Kovacsik, Isabelle Vachier, Nicolas Molinari, Arnaud Bourdin

\section{- To cite this version:}

Sébastien Bommart, Hélène Kovacsik, Isabelle Vachier, Nicolas Molinari, Arnaud Bourdin. Softwareassisted Computed Tomography Quantification of Airway Remodeling in the Normal Aging Process. American Journal of Respiratory and Critical Care Medicine, 2017, 195 (4), pp.540 - 541. 10.1164/rccm.201610-2028LE . hal-01783516

\section{HAL Id: hal-01783516 https://hal.science/hal-01783516}

Submitted on 12 Dec 2019

HAL is a multi-disciplinary open access archive for the deposit and dissemination of scientific research documents, whether they are published or not. The documents may come from teaching and research institutions in France or abroad, or from public or private research centers.
L'archive ouverte pluridisciplinaire HAL, est destinée au dépôt et à la diffusion de documents scientifiques de niveau recherche, publiés ou non, émanant des établissements d'enseignement et de recherche français ou étrangers, des laboratoires publics ou privés. 


\section{Software-assisted Computed Tomography Quantification of Airway Remodeling in the Normal Aging Process}

\section{To the Editor:}

We have read, with great interest, the article by Martinez and colleagues, recently published in the Journal, on the effects of aging on pulmonary computed tomography (CT) (1). The authors claim to have novel findings about lung aging, foremost among which is the association between age and functional airway abnormality identified using post-processing chest CT images.

However, this finding has already been reported in a well-defined, healthy elderly population above 60 years of age without related symptoms or standard pulmonary function testing abnormalities (2). This study by Bommart and colleagues demonstrated a linear relationship between air trapping quantification as a reflection of small airway obstruction and age (2). Air trapping was processed using expiratory-to-inspiratory ratios of mean lung density, which is also a validated tool to assess the small airways quantitatively, and was correlated with functional parameters linked to distal obstruction $(3,4)$.

The article by Martinez and colleagues reports supplementary information about middle-aged populations and also observed the more pronounced small airway obstruction in their oldest subjects (1). We think that small airway obstruction related to age is, indeed, most relevant in this elderly population. In fact, as the authors rightly pointed out, this phenomenon impacts functional analysis and could also contribute to disability among the oldest people.

Quantitative CT imaging offers new insight into the scope and limits of lung and airway abnormalities, especially at the level of the small airways, which play a major role in obstructive diseases, while remaining beyond the zones that most pulmonary function tests evaluate. Furthermore, it is particularly noteworthy that this finding could be assessed using different technical approaches, such as Parametric Response Mapping or expiratory-to-inspiratory ratios of mean lung density. The variability related to age could be factored into clinical research using quantitative CT imaging. Also, the limits between normality and disease should now be assessed, as done by functionalists (5), and updated using a large range of the population to put forward radiomics as a reference tool to monitor small airway diseases.

\footnotetext{
www.atsjournals.org.

Sébastien Bommart, M.D., Ph.D.

Hélène Kovacsik, M.D., Ph.D.

Isabelle Vachier, Ph.D.

Nicolas Molinari, Ph.D.

Arnaud Bourdin, M.D., Ph.D.

Centre Hospitalier Universitaire de Montpellier

Montpellier, France
}

Author disclosures are available with the text of this letter at article, Bommart and colleagues found that in 101 subjects, aging mainly affected distal airways of healthy volunteers older than 60 years of age. The relationship between age and computed tomography (CT)-derived measures of expiratory to inspiratory ratios of lung density as a measure of air trapping in addition to ratios of wall thickness to wall area were examined in univariate analyses. Their contribution to the field certainly deserves to be acknowledged.

We believe our work extends these findings in several important ways. We used a different technique to quantify areas of nonemphysematous gas trapping, specifically parametric response mapping, which uses dynamic coregistration of inspiratory and expiratory CT images. The size of our cohort and use of multivariate models allowed us to test the association between age and small airway abnormality while controlling for potential confounders, including sex, race, height, smoking status, smoking history, and history of asthma. We were able to demonstrate that older age appears to be associated with CT-defined functional small airway abnormality regardless of respiratory symptoms. Finally, we also analyzed individuals with airflow obstruction and found that in these individuals there is greater effect of age on the extent of parametric response mapping-defined functional small airway abnormality; for the same degree of airflow obstruction, subjects of more advanced age have greater small airway abnormality than those of younger age. We thank Bommart and colleagues for their letter highlighting their important contribution to this field.

\section{References}

1. Martinez CH, Diaz AA, Meldrum C, Curtis JL, Cooper CB, Pirozzi C, Kanner RE, Paine R III, Woodruff PG, Bleecker ER, et al.; SPIROMICS Investigators. Age and small airway imaging abnormalities in subjects with and without airflow obstruction in SPIROMICS. Am J Respir Crit Care Med 2017;195:464-472.

2. Bommart S, Marin G, Bourdin A, Revel MP, Klein F, Hayot M, Vachier I, Chanez P, Picot MC, Mercier J, et al. Computed tomography quantification of airway remodelling in normal ageing subjects: a cross-sectional study. Eur Respir J 2015;45:1167-1170.

3. Mets OM, Murphy K, Zanen P, Gietema HA, Lammers JW, van Ginneken B, Prokop $\mathrm{M}$, de Jong PA. The relationship between lung function impairment and quantitative computed tomography in chronic obstructive pulmonary disease. Eur Radiol 2012;22:120-128.

4. Bommart S, Marin G, Bourdin A, Molinari N, Klein F, Hayot M, Vachier I, Chanez P, Mercier J, Vernhet-Kovacsik H. Relationship between CT air trapping criteria and lung function in small airway impairment quantification. BMC Pulm Med 2014;14:29.

5. Quanjer PH, Stanojevic S, Cole TJ, Baur X, Hall GL, Culver BH, Enright PL, Hankinson JL, Ip MS, Zheng J, et al.; ERS Global Lung Function Initiative. Multi-ethnic reference values for spirometry for the 3-95-yr age range: the global lung function 2012 equations. Eur Respir J 2012;40:1324-1343. 